\title{
RESIDENTIAL CONDITIONS FOR IMMIGRANT POPULATION
}

\author{
ANA L. ALVAREZ \& DANIELA MÜLLER-EIE \\ Department of industrial economics, risk management and planning, University of Stavanger, Norway.
}

\begin{abstract}
The arrival of large immigrant populations affects the social as well as the urban structure of the host cities. Immigrants with similar ethnic and social background often occupy segregated areas in host cities, where residential conditions are systematically different from other areas. Residential conditions consist of citywide aspects (spatial distribution, transportation network), neighbourhood facilities (public space, amenities) housing standards (size, occupation, facilities). Based on a literature survey, these concepts are defined through parameters. Specific demographic profiles of immigrants can be identified (country of origin, age, sex, employment status, economic status, religion, economic situation or length of stay in the host area) in order to explore specific residential conditions in the case study cities). The paper presents a model of relationship between immigrant population and residential conditions on the different levels. Here, the level of spatial integration or segregation is of particular interest. Some of these parameters are illustrated by examples from Oslo and Stavanger.

Keywords: housing quality, immigration, integration, neighbourhood quality, residential conditions, segregation.
\end{abstract}

\section{INTRODUCTION}

Migration has long been an important topic in European countries. In Norway, particularly work immigration has played an important role. There seems to be a reciprocal relationship between immigration, spatial structures and residential conditions in the host city and spatial segregation/integration.

This paper therefore explores the mechanisms of immigration as well as residential conditions that meet immigrants in the host cities. These concepts are operationalised, together with their indicators and parameters, based on a literature survey.

The mutual impact that these concepts have on each other is also described. It is further of interest if there are certain spatial or social conditions that can contribute to a better spatial integration of immigration population into the host city. The purpose of this paper is therefore to get a better understanding of immigration settlement in specific areas.

\section{IMMIGRATION}

Immigration is defined as an action by which a person establishes his or her usual residence in a country for a period that is at least 12 months, having previously been usually resident in another country [1]. Immigration has become one of the key components of population change. Migration flows have over the past decades had a significant impact on the current population size in most EU member states. The migration network, i.e. the interaction that connects the migrant and their country of origin with the country of destination, is influenced by a combination of economic, political and social factors; either in the migrant's country of origin (push factors) or in the country of destination (pull factors) (Fig. 1) [1].

In order to understand how an immigrant population is inserted in the host city we need knowledge about migratory phenomena. Migration can be viewed from a macro and micro perspective [2]. In the macro perspective, the immigrant is considered as a passive individual who responds to the structural forces that determine his mobility; in the micro perspective, 


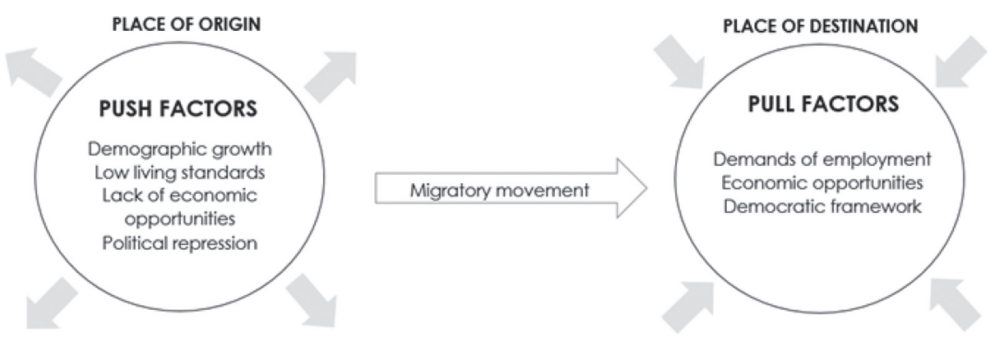

Figure 1: Push and pull factors for migration.

the individual characteristics of the immigrant are emphasised, considering them as influential factors for the decision and in the way in which the individual interacts and adapts to the new environment. This research therefore focuses on the latter perspective, as personal characteristics and attitudes towards the host country are most relevant.

The macro perspective has been dominant historically, representing two paradigms. First, the theory of modernization where migration is conceived as a process of improvement/ progress, where the individual moves from a poor country or region to a richer one, driven both by the factors of expulsion (push) and the factors of attraction (pull). Secondly, the theory of dependence conceives migration as a macro process between countries, where migration is not an improvement process but a mechanism of extraction of surplus and income from the dependent and underdeveloped countries to the developed ones [3].

Migration may be a consequence of demographic change, but it is also, in itself, a demographic change. Migrations constitute one of the three components of demographic change, besides birth and mortality [4]. It also interacts bidirectionally with the other two, especially with birth, meaning that immigration is both cause and consequence of population growth, birth rate and age structure. The consequence effect on migration may be induced by the slow growth of the population, by the low fertility and by an aging age structure; and cause because it contributes to population growth through a likely increase in aggregate fertility and mitigation of an aging population.

Furthermore, immigration produces economic and social effects by itself, different from those resulting from the other components of demographic change. In fact, the social and economic impacts of immigration often matter more than demographic. Therefore, the sustained arrival of immigrants and their setting-up in new societies can assume a social and economic transformation in the future.

\subsection{Immigrants and the city}

The arrival of immigrants in European cities is transforming their structure, leading to irreversible changes of territorial and social concentrations of ethnic diversification, changing social and cultural composition and generating new social needs, with the consequent problems of coexistence and urban segregation [5]. Cities attract due to economic opportunities, cultural, social, sports offers; they are places of relationships, contacts, creativity and innovation. Historically, large urban centres have always been areas of greater freedom, refuge for the poor and minorities. This has encouraged many people to emigrate, not to specific countries, but to cities [6].

Sassen and Portes [7] identify global cities as those that have become central nodes for the coordination and administration of the world capitalist economy (e.g. New York, London and 
Tokyo). They extend their analysis to smaller cities, which perform similar functions of order and control on a regional scale. These are considered 'global cities of second rank', entities defined by capital flows, information and technology that play an important role in supranational spaces. Cities that have moved in this direction are characterised by a new cosmopolitan atmosphere and by an abundant presence of immigrant population.

\subsection{Location choices among immigrant population}

Immigrants have historically played an important role in demographic and economic development, particularly in cities. It is therefore important to study the factors that explain initial and subsequent location choices among immigrants.

Location preferences can be based on pull factors of the area of destination. Immigrants are attracted to regions with labour market opportunities, existing immigrant populations, housing market possibilities, as well as welfare benefits. However, these preferences may be of personal nature (education, family ties, predilection) and differ between initial and subsequent stages.

\subsubsection{Labour market}

Labour market conditions, such as average wages and the level of unemployment, affect where immigrants settle [8]. Opportunities to find a job and have sufficient wages are decisive in the decision to migrate, as well as the need to guarantee economic self-sufficiency (i.e. covering the economic needs of oneself and the dependent family). In addition, access to the jobs for which immigrants are qualified or have experience in is another factor when joining the labour market in the host country. Another factor is the length of contract, being permanent or temporary. This is affected by the legal status of the immigrant, the duration of the immigrants work permit or the degree of instability of the labour sector. The majority of the immigrant population aims to integrate into the labour market to improve their economic quality of life and is therefore likely to settle in areas where a prompt and stable insertion into the labour market is possible [9].

\subsubsection{Existing immigrant population}

The number of immigrants in a given area has an attraction effect itself [10], so the higher the number of existing immigrants, the greater is the areas power of attraction. The tendency for immigrants to settle in neighbourhoods where other immigrants are present, regardless of the country of origin, appears to be important as first initial location choice of urban area. Due to this self-enforcing process, metropolitan areas may tend to receive more immigrants in the future [11].

\subsubsection{Housing market}

Other structural factors inhibit the residential insertion of immigrants, for instance the local housing market. Here, discrimination can produce an imbalance in housing tenure favouring owner occupation and residual social housing [12]. In contrast, the informal housing markets have been working as an attraction factor for migration streams, influencing location choices. Informal housing market often translated into insecure tenancies, poor housing quality, speculation and exploitation of the markets, structuring housing (sub) markets or 'unregulated' policies.

The type of the housing from the immigrant population is characterised by its size and diversity, due to the extensive family network and habitability strategies linked to the first stage of arrival of the migration process. 
In a certain urban structure, the access to the house market acts as a determinant filter in the distribution of the immigrant population, meaning a spatial exclusion that directly affects the economic structure of the correspondent area.

Housing market is related to immigrant population by conditioning their location and as an indicator of the living conditions and social position of immigrants. It is therefore fundamental for the spatial and social integration process.

\subsubsection{Urban cores}

Many European cities have thus become gateways for immigrants. The spatial pattern of immigration has always been characterised by a high concentration of immigrants in the central city cores of the metropolises [13].

However, this spatial pattern has recently started to change, and immigrant flows are now characterised by decentralisation. On one hand, the reason for this is that the gateways have been saturated and so the geographical concentration has ended. On the other hand, the decentralisation is related to migration settlement in working class areas on the periphery [14].

The above described mechanism of immigration can be used to identify specific immigrant groups to explore their relationship with the studied host cities, in particularly their residential conditions.

\section{RESIDENTIAL CONDITIONS}

In order to understand better what this encompasses, the concept of residential conditions must be explored. Residential conditions entail different scales, from the dwelling itself to the neighborhood or city in which it is located. Parameters such as availability of services and facilities in an area, habitability or required living space, accessibility and spatial distribution in the city define the concept of residential conditions.

Depending on the location of the dwelling, i.e. the spatial distribution of immigrant groups in the city leads to spatial integration or segregation. The level of integration (or lack thereof, i.e. segregation) has consequences for residential conditions.

Residential conditions are considered adequate when the dwelling is located in an urban area that allows access to employment, public urban areas and facilities, access to public transportation as well as public health and educational services, meaning that it is comparable with that of other residents in the city. Regarding housing quality, a dwelling needs to be functional, secure, habitable and accessible. The main question here is, whether specific groups of immigrants are more likely to suffer from negative residential conditions than others.

\subsection{Spatial segregation and integration}

The study of the spatial distribution of immigrant population in urban areas has always focused on the concept of residential segregation. The notion of segregation involves the unequal distribution of different population groups in the urban space and has a strong correlation with social differentiation [15].

White [16] identifies two types of segregation. First, the geographic, which exists when some areas show an overrepresentation and other areas an under-representation of a particular population group; second, the sociological, which occurs when there is no interaction between social groups. Spatial segregation suggests social differences, e.g. the dwellings, their characteristics or their location reflect the social hierarchy of a city. Social inequality and 
unequal value of space constitute the foundations of segregation in cities. It is possible that there is sociological segregation without geographic segregation.

\subsubsection{Factors of residential segregation}

One of the fundamental issues with segregation is the identification of factors and characteristics. Urban structure, migration, local welfare state and the general characteristics of the local society tend to influence segregation. White [16] points out three factors inductive to this process.

First, the socio-economic factor. People with similar socio-economic conditions (e.g. low-income) cluster together. This socio-economic segregation of the population is reflected in residential segregation.

For the second, the demographic factor, Bayona and López [17] point out that the degree of residential mobility and the housing structure influence the residential differentiation among immigrants. Different migratory stages can relate to different types of housing. Thus, the evolution of the housing structure linked to residential mobility, generates different forms of settlement and segregation in a city at different stages of the migratory process.

The third factor is the ethnic factor, relating to social differences based on ethnicity. This factor affects specially collectives that differ from the host society in linguistic, religious and cultural terms and tend to reside in concentrated neighborhoods (Fig. 2). The degree of residential segregation is also conditioned by other factors. For instance, the urban structure: Cities are defined by their structural heterogeneity and diversity [18]. Thus, urban morphology, residential hierarchy and housing market are the conditioning factors for the distribution of the immigrants [16].

Also, the characteristics of migratory flows, meaning the intensity or type of immigration (for example migratory waves, whether legal or not): The relationship between the migratory phenomenon and the city begins with the absorption by a specific urban context of a migratory flow. The characteristics of this specific flow will influence the capacity and form in which the city will absorb the new population. The degree of intensity of the migratory flows, and the fact that they are irregular, determine the city's capacity to absorb such flows and, therefore, the degree of segregation.

Finally, the stages of migratory flows: The immigrant population's settlement in the city has to be understood as a dynamic process involving different stages; the arrival, settlement and stabilization stage. With the improvement of the economic and legal status, residential conditions and relationship with the host society will vary accordingly.

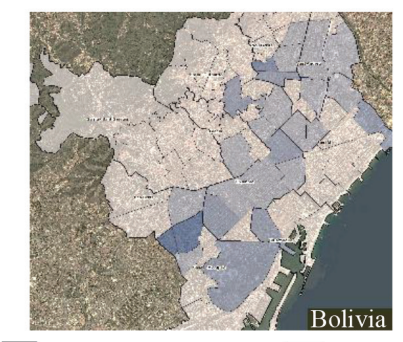

0 - 555 immigrants

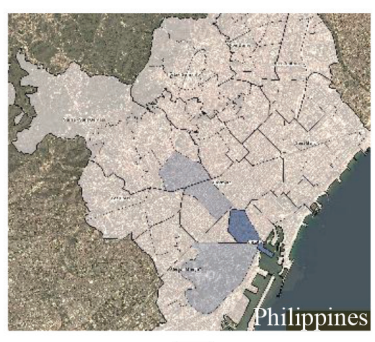

$1.096-1.638$ immigrants

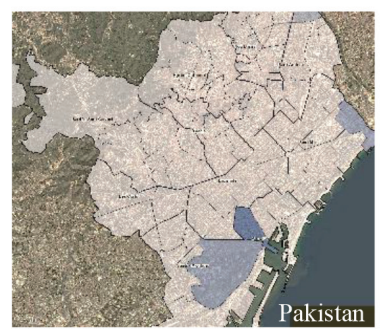

$1.638-2.179$ immigrants

Figure 2: Distribution of immigrants after nationality, by districts, Barcelona Metropolitan Area, 2013. (Fundació ACSAR). 


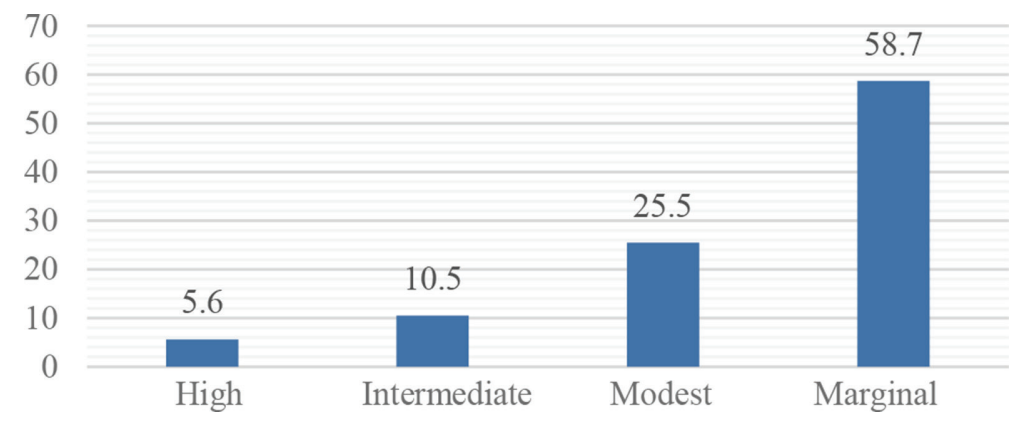

Figure 3: Density of immigrants between neighbours, according to the social level of the neighborhood. (Colectivo IOÉ, 2014).

\subsection{Connectivity and public facilities}

The characteristics of the neighborhood are defined by several aspects, as the connectivity to the rest of the city through private or public transport, access to public spaces and services (meeting places, health facilities, daycare, schools) and daily amenities (grocery shops, pharmacy). Access to basic facilities, such as public transportation, grocery stores and health care services within the neighborhood refers to the ability of households to cover basic needs.

An efficient public transport connection to the rest of the city is relevant for work travel, but also closely linked to the concepts of spatial integration and segregation. A good transportation system contributes to a good access to the different services and facilities that the whole city offers. Similarly, the existence of public space and green areas located in the neighborhood, allow the immigrant to socialize and integrate with other neighborhood residents. Mixed-use neighborhoods are generally strong in providing for these daily needs within a short distance of the home.

The ratio of immigrants to local population is related to the status of a neighbourhood in terms of its integration, accessibility, quality of public facilities, as well as in terms of social status (security, crime, employment, income) (Fig. 3). A common feature in European cities is that the concentration of immigrant households occurs in inverse correlation with the status of the neighbourhood, with the consequent problems of ethnic segregation in the degraded or marginal areas of the city; i.e. the lower status, the greater concentration of immigrant population [19].

Other aspects of neighborhood quality are more subjective to conceptions in the population, due to different sensitivities or expectations. The most frequent complaints for both local and immigrant populations, are the lack of cleanliness in the streets, noise, vandalism, delinquency, environmental pollution and problems of connectivity and transportation to the rest of the city [20].

\subsection{Housing}

People's ability to afford adequate housing in a safe environment is a matter of importance for meeting basic needs. Housing quality covers a wide range of aspects: structural problems of the dwelling, overcrowding and space shortage, housing deficiencies and lack of basic amenities are key elements for assessing housing quality [21]. 


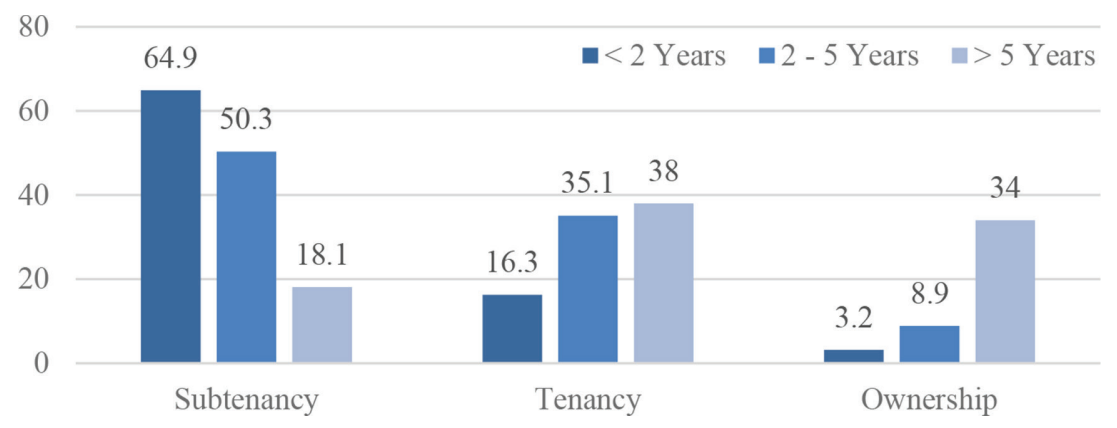

Figure 4: Housing tenure regimen for immigrant population in Spain according to length of stay, 2005. (Colectivo IOÉ, 2014).

The rise of housing prices from the late 1990s have generated problems of polarization and segregation in the access and quality of housing for immigrants, especially for those who are in the period of settlement and do not have consolidated family networks. Housing conditions are also a barrier for achieving a higher standard of living. The type of housing, the tenure regime, household services, economic household situation and neighbourhood factors, define these opportunities [19].

Home ownership is a considerable asset for households since the property right increases the wealth of the household. In 2015 in the EU-28, 70.5\% of nationals from 20 to 64 years of age lived in owner-occupied dwellings, compared with $32.1 \%$ of all foreign citizens of the same age group [22]. There are several reasons for differences between immigrants and locals in terms of the housing tenure. First, rental housing may be the most suitable option for arriving foreigners; however, as their stay is consolidated and the immigrant integrates in the host city, ownership can be considered (Fig. 4).

Another element is the availability of sufficient space in the dwelling. An indicator that describes this problem is the overcrowding rate, defined by the number of rooms available to the household, the household size, its members' age and family situation [21].

Several indicators help to evaluate the quality housing conditions. However, subjective assessments on the degree of satisfaction with the dwelling are used as a measure in order to complement this evaluation. Those subjective satisfaction assessments encompass a number of factors, such as the price, space, distance from home to work and the overall quality of the dwelling.

The above presented parameters for residential conditions can be translated into quantitative and qualitative indicators, such as type of housing, tenure, occupation. This allows specific conditions to be evaluated and compared.

\section{MODEL OF RELATIONSHIP}

Based on the presented information, a model of interaction between the city, the immigrant population and residential conditions is developed (Fig. 5). This model relates the three concepts based on specific parameters. Cities that are characterised by a high percentage of immigrant population are the main target of investigation. Here, the residential conditions of a certain immigrant group can be mapped and investigated. The interaction between the immigrant groups with the city is reciprocal and highly defines how the immigrants are spatially integrated. At the same time, the residential conditions of immigrants also transform the city. 


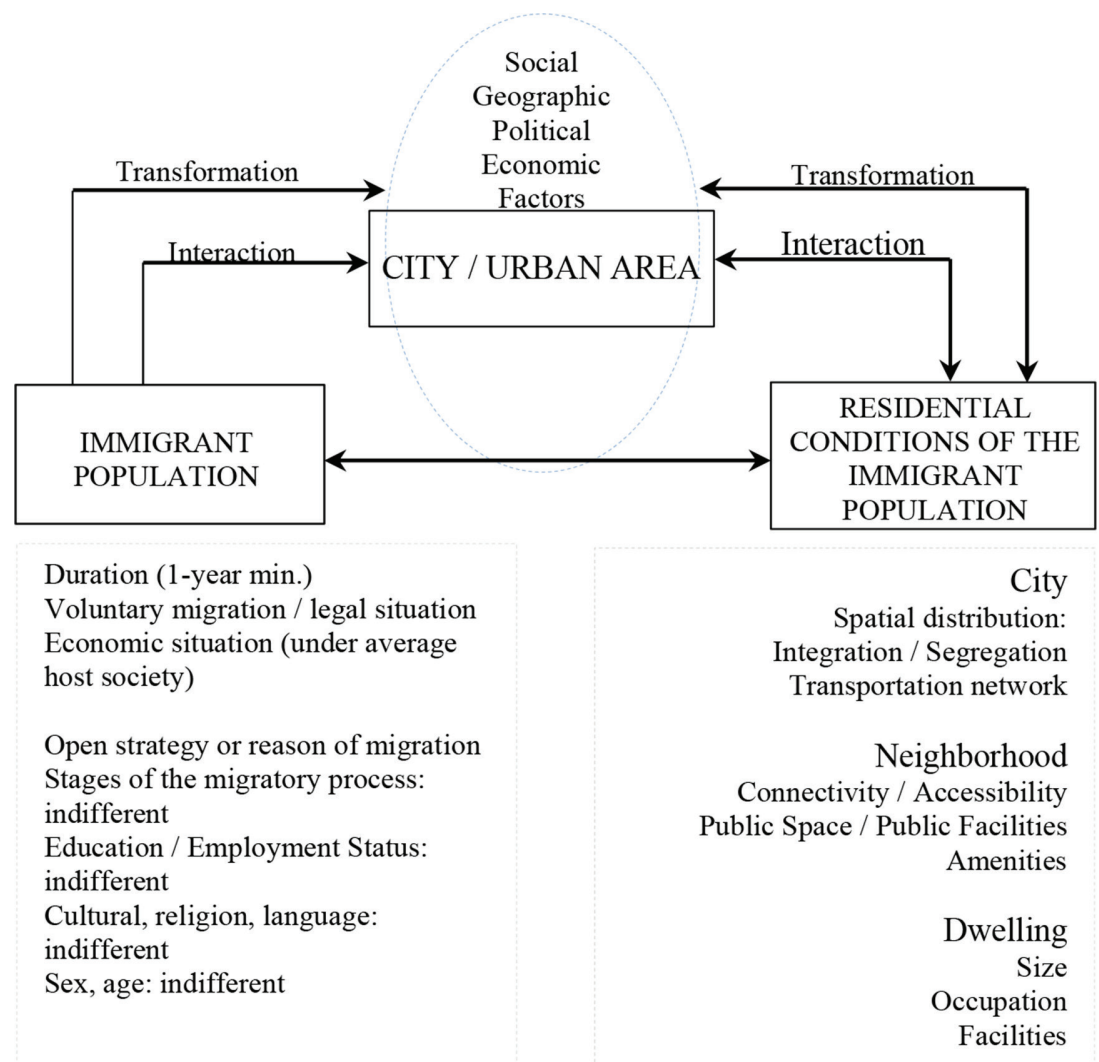

Figure 5: Relationship between the city, the immigrant population and residential conditions.

Any investigation of these relationships is specific to a certain period in time, in which the city is under certain social, geographical, political and economic conditions. This may vary throughout the research process, and may be specific to the city of interest.

Cities or urban areas characterized by a high presence of immigrant population are the subject of the study. Certain parameters, like the economic status, length of stay and religion, can define the group of immigrants that is investigated. Once this group is identified, the interaction between this immigrant group and the urban context can be studied, as well as the possible transformation of the host city structure due to this specific groups' settlement.

The other concept in the model is residential conditions, linked to the specific group of immigrants that is selected. Indicators at different levels, i.e. citywide, neighborhood and dwelling, define these residential conditions. These conditions can also have a transformative effect on the urban structure, but it is reciprocal. Social, political, geographic or economic changes in the city can imply transformations in the residential conditions.

The purpose of this theoretical model is to serve as a basis for empirical investigation of immigrant settlements in specific urban areas, as well as their residential conditions. After establishing the level of spatial integration/segregation, the focus is whether certain immigrant groups live under systematically worse conditions than other immigrant group or than local 
residents. An additional qualitative investigation into their perception of residential conditions can help to understand the level of their well-being.

\section{IMMIGRANT POPULATION IN OSLO AND STAVANGER, NORWAY}

Norway, being a large country sparsely populated has always been depending on immigration. While birth rates are relatively high (1.73\% in 2014) it is difficult to serve the blue-collar section of the labour market through locals. Additionally, the oil industry in western Norway has contributed to work immigration in the white-collar labour marked [1]. Today $13.4 \%$ of people living in Norway are immigrants. As Table 1 shows, both Oslo and Stavanger have a high percentage of immigrant population and its corresponding projections. While both Oslo and Stavanger have large immigrant populations, they also differ. Oslo, the capital, attracts larger numbers and more diverse immigrants; while Stavanger, the oil capital, attracts particular work immigrants for the petrol industry and related industries.

A large part of the immigrant population has migrated to Stavanger for work reasons $(31.1 \%)$ or for family/personal reasons $(24.5 \%)$. The rest are refugees $(20.6 \%)$ or immigrants due to education or similar reasons (6.3\%) [23]. In 2016, the amount of immigrant population with European background in Stavanger was 51\%, while $29 \%$ had an Asian background. In Oslo, the highest percentage was Asian (40\%), followed by European (38\%) and African $(17 \%)$. This might be due to a higher level of work immigration in Stavanger, for instance for construction sector.

Among the immigrant population in both cities, there are certain nationalities that dominate above the rest. Figure 6 shows the seven most represented nationalities in each city.

The unemployment rate among immigrants is relevant. In this case, the unemployment rate is analysed according to nationalities and in comparison to the Norwegian society. This parameter helps to define the group of immigrants to be investigated, since immigrants who are economically challenged are of particular interest in the exploration of residential conditions.

In Stavanger, the largest group of unemployment immigrants is from Eastern Europe (25\%) and the smallest group (4\%) is from Africa [24]. This is due to a generally large population of Eastern Europeans in Stavanger.

The immigrant population in Oslo is unevenly distributed throughout the city, meaning that certain districts show higher percentages of immigrants than others. The majority of the immigrant population living in Oslo resides in the districts of Frogner, Grünerløkka and Gamle Oslo (Fig. 7). From these districts, three smaller neighbourhoods can be selected based on a particularly high ratio of immigrants vs. locals: Lille Tøyen (25\%), Haugerud (72\%), Ensjø (37\%) [24]. Exploring these immigrant populations and analyzing their residential conditions can help to understand living conditions for immigrants in Norway in general.

Table 1: Population data, Stavanger and Oslo. (KommuneProfilen.no, 2017).

\begin{tabular}{|c|c|c|c|c|c|c|}
\hline & $\begin{array}{l}\text { Total } \\
\text { Population }\end{array}$ & $\begin{array}{l}\text { Immigrant } \\
\text { Population }\end{array}$ & $\begin{array}{l}\text { Immigrant } \\
\text { Population } \\
(\%)\end{array}$ & $\begin{array}{l}\text { Total pop. } \\
\text { Expectations } \\
(2030)\end{array}$ & $\begin{array}{l}\text { Immigrant } \\
\text { total pop. } \\
\text { expectations } \\
(2030)\end{array}$ & $\begin{array}{l}\text { Immigrant \% } \\
\text { Pop. Expecta- } \\
\text { tions (2030) }\end{array}$ \\
\hline Stavanger & 132644 & 29307 & $22.1 \%$ & 141634 & 46511 & $32.8 \%$ \\
\hline Oslo & 658390 & 214213 & $32.5 \%$ & 788928 & 305731 & $38.7 \%$ \\
\hline
\end{tabular}



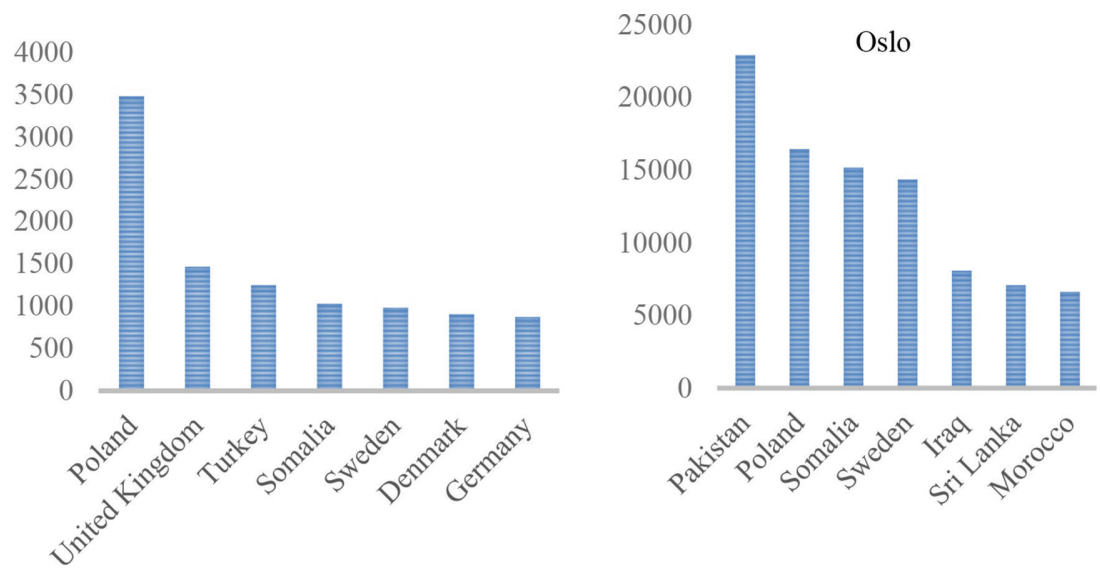

Figure 6: Immigrant population distribution in Oslo, 2016. (KommuneProfilen.no, 2017).

Table 2: Employment data, Stavanger and Oslo. (KommuneProfilen.no, 2017).

\begin{tabular}{llll}
\hline & $\begin{array}{l}\text { Total unemployment } \\
\text { population }\end{array}$ & $\begin{array}{l}\text { Norwegian unemployment } \\
\text { population }\end{array}$ & $\begin{array}{l}\text { Immigrant unemployment } \\
\text { population }\end{array}$ \\
\hline Stavanger & $2.9 \%$ & $2.2 \%$ & $5.4 \%$ \\
Oslo & $1.6 \%$ & $1.1 \%$ & $2.8 \%$ \\
\hline
\end{tabular}
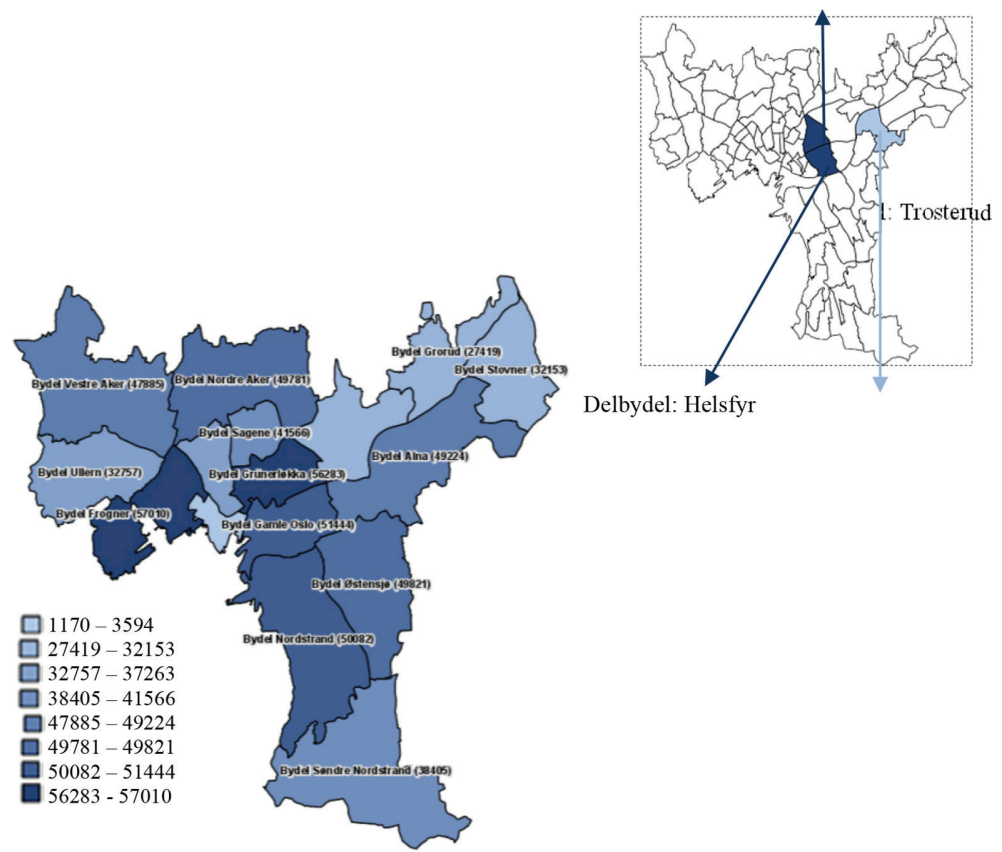

Delbydel: Helsfyr

Figure 7: Immigrant population distribution in Oslo, 2016. (oslo.kommune.no). 
In Stavanger, a similar concentration of immigrants in one district (Storhaug) can be found [25]. This uneven spatial distribution of immigrants in the host cities suggests that there are mechanisms supporting spatial segregation. It is also likely that these areas are characterised by particular residential conditions, such as small dwellings, rental apartment and low rent. Investigating these conditions further can give some insight into how immigrants could be better spatially integrated in the host cities in the future.

\section{CONCLUSION / DISCUSSION}

Based on the presented literature and data, the developed model for relationships between the city, immigrant population and residential conditions is a good starting point for further empirical investigation and theoretical exploration. The purpose is to be able to describe and analyse the residential conditions of a given group of immigrant population in terms of their physical environment, in order to improve the quality of life of this population. By operationalising the concepts of immigrant population and residential conditions, it is possible to see if there are significant differences in living conditions for different population groups in Norwegian cities. The level of spatial integration/segregation is of particular interest here, since it can possibly contribute to a higher level of social integration.

This paper is part of a larger $\mathrm{PhD}$ study called 'Residential conditions for immigrants in Norwegian cities and their effect on the quality of life'. An investigation of specific groups of immigrant in Oslo and Stavanger, as described in this paper, is launched in order to gain a better understanding for the relationships between immigration, the urban structure, residential conditions and quality of life.

\section{REFERENCES}

[1] EUROSTAT. Migration and migrant population statistics, 2013. Available at http:// ec.europa.eu/eurostat/statistics-explained/index.php/Migration_and_migrant_ population_statistics

[2] Fullaondo, A., Elordui-Zapaterietxe, "Inserción y lógica residencial de la inmigración extranjera en la ciudad. El caso de Barcelona," 2008.

[3] Portes, A. \& Böröcz, J., Contemporary immigration: Theoretical perspectives on its determinants and modes of incorporation. International Migration Review, 23, pp. 606-630, 1989. https://doi.org/10.2307/2546431

[4] Siegel, J.S., Demographic aspects of aging and the older population in the United States. US Dept. of Commerce, Bureau of the Census: for sale by the Supt. of Docs., US Government Printing Office, 1976.

[5] Llovera, M.D.V. \& Cabral, A., Inmigración transnacional, ciudad y segregación urbana: espacios de desigualdad social. Zainak. Cuadernos de Antropología-Etnografía, 32, pp. 1015-1024, 2009.

[6] Dura-Guimera, A., Population deconcentration and social restructuring in Barcelona, a European Mediterranean city. Cities, 20(6), pp. 387-394, 2003. https://doi.org/10.1016/j.cities.2003.08.004

[7] Sassen, S. \& Portes, A., Miami: a new global city?. Contemporary Sociology, 22(4), pp. 471-477, 1993.

https://doi.org/10.2307/2074362 
[8] Borjas, G.J., Immigration and welfare magnets. Journal of Labor Economics, 17(4), pp. 607-637, 1999.

https://doi.org/10.1086/209933

[9] De Coulon, A. \& Wadsworth, J., On the relative rewards to immigration: a comparison of the relative labour market position of Indians in the USA, the UK and India. Review of Economics of the Household, 8(1), pp. 147-169, 2010.

https://doi.org/10.1007/s11150-009-9065-6

[10] Rogers, A. \& Henning, S., The internal migration patterns of the foreign-born and native-born populations in the United States: 1975-80 and 1985-90. International Migration Review, pp. 403-429, 1999.

https://doi.org/10.2307/2547702

[11] Åslund, O., Now and forever? Initial and subsequent location choices of immigrants. Regional Science and Urban Economics, 35(2), pp. 141-165, 2005. https://doi.org/10.1016/j.regsciurbeco.2004.02.001

[12] Fullaondo, A. \& Garcia, P., Foreign immigration in Spain: Towards multi-ethnic metropolises. In Paper at ENHR International Conference Rotterdam, 2007.

[13] Malheiros, J.M. \& Vala, F., Immigration and city change: the Lisbon metropolis at the turn of the twentieth century. Journal of Ethnic and Migration Studies, 30(6), pp. 1065-1086, 2004.

https://doi.org/10.1080/1369183042000286250

[14] Martori, J.C. \& Apparicio, P., Changes in spatial patterns of the immigrant population of a southern european metropolis: The case of the Barcelona Metropolitan Area (20012008). Tijdschrift voor economische en sociale geografie, 102(5), pp. 562-581, 2011. https://doi.org/10.1111/j.1467-9663.2011.00658.x

[15] Bayona-Carraco, J. \& Gil-Alonso, F., Suburbanisation and international immigration: The case of the Barcelona metropolitan region (1998-2009). Tijdschrift voor economische en sociale geografie, 103(3), pp. 312-329, 2012. https://doi.org/10.1111/j.1467-9663.2011.00687.x

[16] White, M.J., The measurement of spatial segregation. American Journal of Sociology, 88(5), pp. 1008-1018, 1983. https://doi.org/10.1086/227768

[17] Bayona i Carrasco, J. \& López Gay, A., Concentración, segregación y movilidad residencial de los extranjeros en Barcelona. Documents d'anàlisi geogràfica, 57(3), pp. 381-412, 2011.

https://doi.org/10.5565/rev/dag.234

[18] Martínez, A.G., Es virtual la realidad de la inmigración?: la construcción mediática de la inmigración extranjera en España. In La inmigración en España: contextos y alternativas, pp. 437-448, 2002. Laboratorio de Estudios Interculturales.

[19] Colectivo, I., Inmigración y vivienda en España. (in Spanish), Madrid: Ministerio de Trabajo y Asuntos Sociales, 2005.

[20] EUROSTAT. Quality of life indicators - material living conditions, 2016. Available at : http://ec.europa.eu/eurostat/statistics-explained/index.php/Quality_of_life_indicat ors_-_ material_living_conditions

[21] EUROSTAT. Housing statistics, 2016. Available at: http://ec.europa.eu/eurostat/ statistics-explained/index.php/Housing_statistics

[22] EUROSTAT. Migrant Integration Statistics - housing. Available at http://ec.europa.eu/ eurostat/statistics-explained/index.php/Migrant_integration_statistics_-_housing 
[23] I. I. o. mangfoldsdirektoratet. Reason of Migration, 2016. Available at: http:// www.imdi.no/tall-og-statistikk/steder/K1103/befolkning/befolkning_innvandringsgrunn

[24] Profilen, K., Population - Structure and Development, 2016. available at: http:// www.kommuneprofilen.no/Profil/Befolkning/meny_befolkning.aspx

[25] Stavanger-statistikken. Innvandrererbefolkningen. Available at: https://regionstatistikk. stavanger.kommune.no/befolkning_15s.html 